\title{
Existentialism is an Antiracism
}

\author{
T Storm Heter, Guest Editor
}

This special issue explores how existential thinking can be a living, global force that opposes racist praxis and thought. We are used to hearing that the "heyday" of existentialism was the middle of the twentieth century. In truth, because existential thought is future-oriented, the heyday of existentialism may be yet to come.

Contributors to this volume were asked to reflect on racism of all sorts, including white supremacist violence, antisemitism, Apartheid, anti-Blackness, settler colonial racism, anti-Indigenous violence, violence against Black women and women of color, neo-colonial racism, and Islamophobia. What draws so many of us to Sartre is the fact that he, more than any other white European existentialist of his time or since, identified with, supported, and philosophized with thinkers from the Global South. The diversity of voices in this special issue affirm that Sartre Studies is about relationships-relationships among people, concepts, and geographies. Because Sartre was a relational thinker, engaging him also means engaging other antiracist existential thinkers such as Simone de Beauvoir, Frantz Fanon, Richard Wright, Aimé Césaire, Lépold Sengor, Albert Memmi, James Baldwin and others.

Sartre wrote unapologetically for his era. How ironic that his "situational" writings remain some of his most inspiring. The contributors to this volume explore how Sartre's decolonial and antiracist writings have a new resonance in the twenty-first century. Coming twenty years after the first volume of Sartre Studies International in 1995, this special edition is indebted to the many editors and scholars across the world who have worked to build the intellectual community that is Sartre Studies.

This special issue features nine essays and two interviews, all original. The contributors come from different backgrounds and they range from senior scholars to graduate students. Besides their stead- 
fast opposition to racism, I hear three commonalities among them. All insist on the need for decolonization-literal decolonization. By literal decolonization I mean a redistribution of land and resources to those formerly colonized subjects in Africa, Asia, the Caribbean, the Americas and elsewhere scarred by European conquest and expansion. Second, all the contributors read Sartre relationally. Instead of treating Sartre Studies as just the study of Sartre's texts, the contributors read him through his relationship with other thinkers. Finally, all the contributors engage in a practice of radical, collective imagination. As Sartre reminded us in everything he wrote, we are condemned to a certain kind of freedom: that of imaginatively transcending our current circumstances. Each contributor, in one way or another, and in their own distinct voice, confronts the gap between the fact of racism and possibility of a more human future.

To orient the reader, I provide here a very short synopsis of the pieces included below. Eddie O'Byrne's interview of Kathryn Sophia Belle outlines some of Belle's major contributions to the philosophy of existence, including her challenge to the "class over race and gender" analysis, her formulation of "the white problem," and her take on Sartre's skepticism of the white, liberal ally. Belle reminds us to read Sartre relationally by keeping in mind the influence of Black interlocutors like Wright, Fanon, Césaire, and Senghor. In her essay on the power of the "coalition," Emma McNicol takes up Belle's challenge to the "race/gender analogy" and offers a counterpoint: Can we imagine a group of "Blacks and whites, women and male workers" forming an all-inclusive worker's movement? For Laura McMahon, it is precisely our ability to imagine a more human future that gives Sartre a continued relevance for antiracist movements. Through a new reading of Sartre's The Imagination and Wright's Black Boy, McMahon argues that anti-Black racist thinking impoverishes the human imagination. Thomas Meagher takes up the limitation of the liberal, white desire to be nonracist. For Meagher, since Sartre's philosophy cannot not offer a complete picture of antiracism, we should read Fanon and Sartre together in an effort to grasp how our "world [is] saturated with white normativity." Robert Bernasconi's and Jonathan Judaken's reflections take the form of a philosophical conversation about privilege, antiracist praxis, and the importance of place. Agreeing with Sartre that racism is a system, Bernasconi and Judaken articulate how antiracist philosophical work demands "a process of unthinking and dismantling." Mabogo P. More emphasizes an important, but lesser-known moment of Sartre's antiracism: his engagement with the anti-Apartheid struggle in South Africa. More not only shows how 
Sartre played a "key role in shaping the anti-Apartheid, anti-colonial, and anti-oppression thinking of Black South Africans in the 60s and 70s," he also offers an existential reading of South African thinkers Steve Biko and Noel Chabani Manganyi. Like More, Leshaba Lechaba maps out Sartre's anti-colonial commitments and relates them to Black liberation struggles in the twentieth and twenty-first centuries. Lechaba treats two social movements as expressions of existential thought: the \#EndSARS movement in Nigeria and the global \#BLM movement. Nathalie Nya submits a fresh reading of Sartre's critique of the French colonial project in Algeria. Nya takes issue with the traditional dyadic understanding of the colonized/colonizer relationship, arguing for the importance of Sartre's depiction of colonialism in the Critique of Dialectical Reason. It is from Fallou Samb's piece "L'existentialisme de Sartre est-il un anti-racisme," that I have borrowed the title of this editor's introduction. Samb pinpoints a simple way for us to practice antiracism: by listening to the Other. Danielle Cervantes offers a Sartrean reading of Ousmane Sembène, the "father of African cinema." Cervantes provocatively reads the figure of the West African griot alongside the European figure of the engaged writer. Justin Fugo's elaborates on Lewis Gordon's notion that decolonization is a collective practice of "love." Fugo details how the commitment to decolonization is an open-ended project, requiring all of us to imagine a future less scarred by racism, patriarchy, capitalism, liberalism, and other "isms" that clog our senses. 
